\title{
The Bumboat Ride
}

\section{Chris Mooney-Singh}

LASALLE College of the Arts, Singapore

A river ferry must have eyes to see. Otherwise, all the watercraft would collide, and the spirits would have a field day. I have explained this to my grumpy dumpling of a driver more times than I care to remember. For this reason he gets his boat re-painted each year with the same green and yellow trim running to where the black hull joins the topside.

"Boss, I tell you all this paintwork is very expensive."

— Are you complaining again, Ah Kok? Just get ready.

Tonight, as usual, the bump-tyre bangs its nose against the pylon making water music. Waves suck at the hull on the cusp of twilight. Two couples step on board and sit port and starboard on the upfront benches with an aisle down the middle. Red luck lanterns dangle from the eaves of the cabin roof, while high on the cheeks of the bumboat's prow, those painted eyes are ready to scare off river ghosts. Below, there are plenty of drowned faces staring up from underwater and lost souls stuck inside tree trunks along the shore, but the ones to worry about are the ghosts of unfinished business carried along from life to life, riding at the back of each passenger's collar.

Keep a lookout, Ah Kok. Put away your smartphone and earbuds.

- He has a weakness for old Cantonese songs.

"Don't worry, Boss. Can multi-task, what."

- There is some interference, Ah Kok.

"But you are all-powerful."

- I have my limitations.

"No, boss. You are everywhere."

- No need to honk my horn. As the mouse deer leaves few tracks, the Water Clan must stay unseen.

"Hey, come along tonight. Slip into a skin, the golden carp one."

- So, you can drift off on the job?

That cheeky, cryptic smile creeps onto Ah Kok's face.

I, the Guardian of the Water Clan, can change my forms like stage costumes and this carp 


\section{SARE, Vol. 57, Issue 1/2020}

skin is my long-term pick. With it, I keep a check on the river's pulse, feel my way with grandfather whiskers, and flash golden scales beneath the boat. Clan duties are more demanding, especially with tourists about. Singaporeans don't waste money on river rides, unless entertaining overseas guests. Soon, all will observe the space-age view of the Marina Bay Sands Hotel, that aerial ocean liner between twin towers with the ArtScience Museum - a lotus-like satellite dish. And no cruise would be complete without observing the spitting lionfish of the nation standing by the water at Merlion Park.

Tonight, even our locals on board have forgotten the danger of drowning during the Month of Hungry Ghosts.

— Ah Kok, are you ready for your fresh batch of passengers? Time to cast off.

Alvin Lee and Fay Fong were on their regular date. Instead of a thrifty food court Friday night, he had surprised her with an expensive French restaurant dinner. Afterwards, the couple strolled along the foreshore and, rather than sitting on a bench to watch the laser light show across the water and the passing traffic of bumboats, Alvin suggested they take a cruise for a change. She shrugged a yes and he went over to the booth to buy tickets. Not going would be ungracious, so reluctantly she walked with him down the planks of the jetty. Getting in first, Alvin steered her over the prow onto the wooden step and to the front seat on the right side of the aisle. The hull jerked at its moorings. What is up with him, she wondered? Why is he going to all this trouble for me? She had been feeling guilty of late, ignoring Alvin's recent attempts to be more than friends, while she had wanted nothing other than cuddle company. As the prow shifted unsteadily on its moorings Fay felt queasy, and her face disappeared into the pocket of his arm and chest. It delighted him. Everything was falling into place. The hull vibrated under their seats.

Fay kept gasping for breath, but Alvin just held her close, until she broke away. "You're choking me!"

"Sorry. I thought..."

She glowered.

Yes, he lost some points.

Meanwhile, the bumboat's body hummed beneath their feet and those of the tourist couple sitting opposite. 


\section{SARE, Vol. 57, Issue 1/2020}

Seated beside her husband, Winifred Drummond was busy sketching an imaginary child. The girl's expression focused forward as if she was the guiding figurehead carved on a ship's prow. The artist also kept a nervous eye on unpredictable Ralph, who could begin dictating at any moment. Winifred had suggested the cruise, hoping he would get on with their story by gleaning a few images from the landscape in the same way she made quick thumbnail sketches.

He was studying each side of a Singapore dollar, seeking a gold-coloured clue about this place. He threw it into the air a few times until his meaty hand fumbled and the coin hit the wooden floor. "Darn!” He looked down at his feet, but it had rolled into a far recess.

"Not to worry," Winifred said, shaking out her blondeness, worn short and hooked over her ears. She wore a loose tank top, sloppy pants and one hint of elegance - a chiffon shawl printed with Chinese peach-blossom branches knotted lightly about her neck. Fifteen years younger, Ralph's condition had forced her to become the heavy lifter in the marriage.

As the boat cut into the channel, words jumped from his brain and he dictated without warning:

Two painted eyes shifted and blinked on the prow, scanning the river for trouble. Amanda was on the lookout for ghosts with her ghoul-meter pointed downwards scanning the water, yet the needle would not budge.

Winifred scribbled while battling a kamikaze mosquito, saying, "Slow down!"

But he continued: “"This dial is playing dead,” Amanda said. "Wake up, silly billy!” Something bright bobbed in the current. "Look! There! I saw it!"”

"Slow it down, Ralph!"

But he was paying more attention to his own thoughts, forming more words in sing-song fashion:

Double drat! Eat my hat!

See a ghost, catch a bat!

Water spirit with no toes

I will catch you by the nose. 


\section{SARE, Vol. 57, Issue 1/2020}

"That's good, but take it steadier, please." Winfred could have recorded him with her mobile phone, but she had purposely left it back at the hotel, switched off for this trip to avoid distractions.

The stopping and starting broke Ralph's flow. Irritated, he aimed fresh Amanda doggerel at his poor wife:

What's up with you, sister?

Did you sit on a blister?

Her American-turned-Aussie could be so exasperating, especially after having a few beers. She had not been able to restrain him at dinner. Medication and alcohol did not go well together. "Be serious, will you. Focus." She was used to his cranky process. He was a brilliant mimic and character builder. The trick was directing the word flow onto the page.

Liquored up, Ralph channeled his comedy-ham side through a mock documentary baritone: "The bumboat started way back as a goods carrier. Known, too, as a junk-floater and dirt barge..."

She tried to butt in, but the alcohol rode roughshod over her: "Derived from the low German 'bomboot', this flat-bottomed vessel chugged all the way through the ages of sail, coal, and oil. Now it is used for pleasure cruises."

Ralph halted, returning to his normal voice, glowering at her. "You want more?"

Winifred kept her patience. "Well, Mr Trivia. I see you've done your homework. Fascinating. Now where's Amanda and that ghost?"

He scratched the back of his ginger hair where it was going grey. Ruddy cheeks and freckles made him look boyish for someone in his late fifties. "I'm tired, Winnie."

The last thing she needed was for her trip to end up as another unproductive booze-cruise water-beetling around a blotto husband. Since Amanda, the Scuba Queen and Amanda Goes Bungee Jumping, she knew Ralph was losing interest in these little chapter novels, even though Amanda Skips Rope along the Great Wall of China had won an international award for children's writing. Thanks to Maxwell, their agent-publicist, Amanda was now speaking in Mandarin, Korean and Japanese. Through selling translation rights, the series was travelling far. To further increase their Asian market presence, the agent had wangled a junket for them to research a lifestyle food feature for The Traveller, while scoping out the beginnings of Amanda, Singapore River Ghost Hunter.

Noting his ebullient temper, she realised Ralph had probably skipped his medication: Goodbye, levelheaded lithium tablets. Welcome, I-need-the-spotlight minor megalomania, 


\section{SARE, Vol. 57, Issue 1/2020}

she thought. He burped up the chilli crab and Tiger Beer from dinner in her face. "Stop it! You can be so disgusting."

He belched again. "I'm real schnockered tonight, Winnie." Despite a third of a lifespan spent in Australia, Ralph's Midwestern slang still came out.

Time to check the Water Clan Log. It floats up slower than usual from the depths, a leatherbound tome with the concave half of a polished jade stone embedded in its cover. My carp whiskers brush across the green and pages light up from inside, flicking open, one at a time. Channel Chi is only loading words and images in slow patches. Something is blocking the transmission. I part-read the first part of this foreigner's entry. I can reference the lives of any person who visits Singapore and the River:

Ralph Drummond, the son of a lawyer, played ice hockey for the Michigan University Wolverines, while he studied liberal arts. He did well in both, including college theater productions which allowed him an outlet to express the polarities in his nature.

The passage told how he began a PhD in Asian Studies, but his extreme nature led to constant drinking bouts, arguments with teammates, students, and his college theatre director after an affair with the lecturer's wife. Known as a wild man, another affair with his Department Head's wife coupled with other complaints ended his college days. This further disappointed his father aspiring to local politics. Given a sum of money, Ralph opted to travel.

I look down at the page. A picture of Ralph boarding a jet for Thailand comes into focus. Further pictures show his travels through Thailand, Indonesia, Brunei, Malaysia and arriving in Singapore short of cash. Here he met an Australian backpacker who said that he could find high-paying seasonal work in Western Australia:

Ralph Drummond worked on lobster trawlers near Geraldton, drove trucks in the Pilbara iron ore mines, and picked wine grapes south of Perth around Margaret River. It was here he met his wife to be, Winifred Whitelaw. 


\section{SARE, Vol. 57, Issue 1/2020}

The pages now flick backwards to load more images between passages. I see Ralph Drummond has a connection with Singapore... I must study this section later. Ralph's entry forms a minor chapter.

Across the aisle closest to shore, Fay's stomach was adjusting to water travel and putt-putt boat music, but the loud man to her left was a new irritation. She flinched at the tourist's lack of decorum.

Eager to read his own situation with Fay better, Alvin noted her disapproving frown! Had he put her in a mood following the stumble? The romantic moment was slipping from his grasp and he wanted nothing more to interfere with his plan. By now, the loud tourists across the aisle were becoming annoying.

Winifred tried to shush her husband. "I will tell Maxwell. No more junkets. They are so wasted on you!"

"Maxwell's an asshole!” Ralph boomed back.

She felt cross. The agent was a friend, someone who understood what she was going through with her marriage and writing partnership. Self-conscious Winifred glanced over again to check whether the Chinese couple were listening, but they appeared to be staring full-steam-ahead. She could not silence Ralph's loud voice. The alcohol had loosened his tongue. He started on one of his Aussie-influenced poems:

It's all about the mind's swing door, brain butchery is bloody, and all those bloody crows that caw when the water hole gets muddy.

Fire the words, stone the crows, let them lie together.

Pretty ditties come to blows inside the thunder weather. 


\section{SARE, Vol. 57, Issue 1/2020}

Yes, she knew the history of his 'thunder weather,' all too well. The best strategy was to jolly him along. "I've always liked that one, darling... Look, we can't muck about here, eh? Amanda's on a timeline."

"Why can't I have some fun?"

Tonight's outing would not go so easily for her.

- Ah Kok! The river ghosts are everywhere. You know this is a dangerous month. The spirits play tricks and accidents happen. Smarten up!

"Yes, boss."

"Come on, sweetie, let's get something more on paper."

He snapped back, megaphoning into her ear, "I contribute my ideas. It's all formula. I'm bored out of my brain."

She still needed to keep on with her purpose. "Relax. Look how much we've achieved. Remember the funky monkey routine you did for that busload of Beijing kids on the Great Wall?"

His eyes lit up as she brought him to a cheerful place.

"Don't you want to write another Amanda story? Your audience loves them."

Ralph did not answer. Instead, he popped up like a jack-in-the-box turning around, back to the prow to act out his children's verse:

Let's do the funky monkey,

let's screech and scratch and hiss,

let's do the funky monkey

and swing our arms like this.

He swung his limbs gorilla-style with accompanying ape-sounds before a captive audience. Yes, he had noted with glee the stunned couple opposite.

He really was too much. His antics could be tiring. "Okay, steady on, Bigfoot." She sat him down, while glancing apologetically at the shocked couple opposite. Winifred regretted bringing him on the boat now. She could medicate him back in their hotel room. Despite his 


\section{SARE, Vol. 57, Issue 1/2020}

wild shifts, they had been a good and productive team. She tolerated his cantankerous flareups, all the while loving the deep-down Ralph who, on better days, was funny, romantic, and generous. Winifred knew that she had saved him from running off a cliff or dispatching a loaded shotgun more than once; tonight, his old ghosts were asserting themselves and a storm was approaching. Spots of rain flecked her cheek. She was glad, at least, to have the flat roof of the ferry above them.

"I'm gonna drag you back to the hotel, Mrs Drummond," he said, making fresh gorilla sounds, putting his arm around her shoulders, clamping his hand tight on her breast.

“Ow!" She pushed him away. "For goodness' sake behave!"

The caveman stood up, rebuffed against the railing, almost toppling overboard.

"Ralph!"

"'Sorright," he slurred, straightening up to become a homo sapiens again.

- Ah Kok! Unplug your music. Pay attention. You are lucky to be a Water Clansman at all, getting drunk on night watch on board the Rajah's war barge. Staring at that girl dancing in front of a fire on shore, then tripping headfirst that night into the river. I should have let you wander among the hungry ghosts for a lifetime to teach you a lesson and get you back on track. Or perhaps I should shift you to a place with less work?

"Where?"

- Pedra Blanca lighthouse duty in the Straits of Malacca, watching for freighters and oil tankers from the Gulf. Pirates will turn up in their attack boats with sharp parangs and guns from time to time.

"Very sorry, Boss."

This wayward brother of mine is not regretful at all. He has taken many births, yet still refuses personal progress. I still hope that serving the Water Clan will help him let go his past ghosts and evolve.

Fay, who wore a ponytail, could not help feeling nervous for the foreign woman trying to control her husband. Managing men through intelligence alone could be tiresome; or was 


\section{SARE, Vol. 57, Issue 1/2020}

travelling on water during Hungry Ghosts Month putting her on edge? According to Chinese belief, this was an inauspicious thing to do. She felt chilly in her sleeveless crimson dress, and, out of instinct, her bare legs and ankle boots snuggled closer to Alvin. Spots of rain wet their faces, but the sky would not decide whether to cascade down.

Had she forgiven him? Alvin took off his light bomber jacket and transferring it to her shoulders, enjoyed the intimacy with his arm around her.

She appreciated the warmth of his gesture and cuddled closer, drifting away with her own thoughts.

After a short while, the bumboat veered toward loud music and the aroma of fried squid wafting across the water. They were passing by Clarke Quay. Tourists, expats, and partygoers were spilling from pubs and clubs with disco sweeties hovering around them like damselflies. Named after the second Governor of the Colony, Sir Andrew Clarke, this fizzy heart of the island had made happy hour into an art form.

With Alvin's mention of Clarke Quay, the face of 'Spicy Andrew' floats to the surface and his Clan Log entry flicks open:

He once enjoyed the local delicacies: barbeque snake, stinky tofu, squid jerky, minnows in peanuts and ate tiger penis for virility. After which, Clarke indulged in 'first rites of passage' with Chinese mainland virgins fresh off the boats.

"I was just a red-blooded Adam in Paradise."

Sir Andrew has told me this, many times.

"The Sultan of Perak cheated me."

This is part of his old litany.

"I never got my seat in the House of Commons."

- Drop it, Sir Andrew. Tonight, I have enough to deal with.

He drifts into the deep current, while the boat steers parallel to the shoreline. 


\section{SARE, Vol. 57, Issue 1/2020}

Fay noticed a group of her colleagues from Axel Sachs \& Associates. They were having dinner in a floating restaurant moored along the quay. Alice Yeo, the office manager was there, along with some sales and marketing people including Cindy Chen who had an arm snaked across some guy with his back facing the water. As the boat passed by, Fay got a shock. It was Phillip! Her heart skipped a beat. She thought he was in New York. Seeing him here excited her but then made her angry because he had not even phoned or texted to say he was back. After losing him more than a year ago, Fay had hidden her dented heart in Alvin's undemanding company. Disturbed, she sat up, separating herself from him, craning her head opposite to see her colleagues.

"Are you okay?"

She said nothing.

He did not understand her sudden agitation and thought it best to give her space. He had been doing so since they first met at a Social Development Unit matchmaking event. It had been an awkward start, until they realised that they had attended the same secondary school, a couple of years apart. Stories of teachers and student pranks had got them talking, giggling and later, going out. She never spoke the word 'date' to any of her friends. After some time, Alvin whispered, "Fay," eager to advance his cause before the boat cruise ended, throwing down his first ill-timed trump of the evening. Rising to salute, he said, "Captain Alvin Lee at your service."

"What are you doing?"

"I got a promotion."

She did not look up. "Good for you," she said with eyes still walking on water towards Phillip Choo on the floating restaurant.

How could she ignore him after such news? Alvin thought. Perhaps they should have stayed on at 'The Balzac', where the foie gras had melted on her tongue, not to mention the crème brûlée served by the Swiss celebrity chef in his black shirt. This was not how things were meant to go tonight. It was time to reveal his surprise. "Hey, I have something for you." Oblivious, Fay was still wondering what to do about Phillip. She did not see Alvin pulling something from his pocket.

He confirmed what was inside, then put it away and waited. 


\section{SARE, Vol. 57, Issue 1/2020}

- Ah Kok, I see Alvin Lee and Fay Fong's names in the Clan Log. Both have lineages that go back to the Mainland Chinese under the British.

Ah Kok continues nodding along with the music, oblivious of what I am saying as he steers the boat under the last bridge of the ferry tour. What to do with you, old friend? You have been here since Prince Sang Nila Utama sailed through the Dragon's Tooth Gate into the Singapore River in 1299. I can still see the entourage as the dragon boats racing here a month ago.

- What have you learned during these past seven hundred years about serving others, Ah Kok?

He remains silent, lost in past music.

Ralph stood up again, rocking dangerously back and forth while looking over the railing. He pointed. "A fish! What a monster, Winnie!"

She looked up from her notepad to see how a huge carp trailing a long mustache leaped from the water, then once more, glinting gold in the moonlight.

"Write this down, he said: "Amanda whirled her fishing line. It plopped out near the fish splash. Sure enough, the giant mouth ran hard with the bait. As the fish took off, the boat followed."

Ralph's mood had changed again. He cleared his throat and without warning, sang:

Like a fisherman's boon

in the month of June,

like a shiny doubloon,

like a piece of the moon,

it's gone, gone, gone.

Winifred wished that she was invisible.

Ralph chortled until a jolt of electricity came through the metal handrail. "Ow!" He lifted his fingers.

— We, of the Water Clan must sometimes administer some gentle psychic 'shock therapy' to wake a subject. Isn't that right, Ah Kok?

"Yes, Boss." 


\section{SARE, Vol. 57, Issue 1/2020}

By now, the Singaporeans could not help staring.

"What are you gawping at?" Ralph said.

They pretended they did not speak English.

He tapped the side of his head with an aggressive index finger. "Hel-lo! Knock-knock. Anyone home?"

Alvin and Fay flinched, drawing upon centuries of Asian restraint.

"Goddamnit!" The boisterous man pulled out a hip flask and took a long swig.

Winifred tried to grab it. "Ralph!"

He pulled it away.

Fay spoke randomly in Hokkien. "Ler si sai ko ah." Ralph turned but didn't understand. Are you psycho? She added in English for the foreigner's benefit. Now she turned fully around to Ah Kok adding, "Ee lang tiah bo!" The boatman did not respond, so she repeated the same words in English for added emphasis: "Say something! No one else is!"

- Ah Kok, don't look away to avoid her.

He recites a proverb to justify himself:

"A wise man lets the birds of trouble fly overhead without letting them nest in his hair."

- Not good enough, Ah Kok. You can't dodge your Water Clansman duty.

Winifred felt her embarrassment growing. "Look stop it! We're in public. Why can't you treat me properly?"

"Like Max?"

"Shush!"

"Stop being so demure, Winnie."

"What are you implying?"

"I know how well you two 'get along.,"

"It's nothing like that!" He was just their publicist and advisor, she restated. "You won't get off your backside. Who else is there to deal with business matters?"

"Business, my foot!" 


\section{SARE, Vol. 57, Issue 1/2020}

Fay's ears pricked up. Her jangled feelings about Phillip needed an outlet. She jabbed Alvin in the ribs to intervene.

Too late. Winifred could not put the bile genie back into Ralph's bottle. "You're always hanging around him like a bitch in heat."

Fay jabbed again. Seeing another woman in trouble was too much.

Winifred was struggling to maintain her dignity. "Stop it!" she said, again trying to snatch the flask from him.

Ralph grabbed her wrist and laughed. "So, you wanna play hardball, huh?"

Things were turning ugly.

Where is this all coming from? Let me see what the Log further reveals about this foreigner. The next page shows a picture of a fat manuscript lodged in the sarcophagus of a filing cabinet. The last sentence reads: "He was kneeling, soaked and muddy on the lip of the dam, the floppy body in his arms."

Since then, Ralph could not progress with his writing. Why is this all coming out now?

— Ah Kok! Turn the wheel. Just a fraction.

The bumboat jerks. Ralph stumbles again. I hate to intervene, but this is not a fair fight against your wife. Time to relieve you of your liquor, Ralph.

The hip flask flew out of his grasp and over the railing. "Goddamn it!" He lurched sideways to save it, making the boat unsteady. "Look what you've made me do!"

“Help her, Alvin!” Fay said.

"It's not our business."

"If you can't stick up for a woman being picked on, how are you going to protect the nation?" Recently Fay had joined the Singapore branch of Aware and had become vocal about abuse and gender issues.

“'Okay, okay!” He swallowed, stood, and addressed the tourists. "Is everything all right?" Fay groaned.

Ralph looked up, ready to be belligerent. "Who the hell are you?" 


\section{SARE, Vol. 57, Issue 1/2020}

"We are the people forced to listen in to your private talk." Alvin turned next to Winifred.

"Are you okay, Ma'am?"

Ralph reacted. "She's my wife. Scram!"

“I'm fine, really I am, young man.' Winifred implored Ralph again, “Darling please.”

But he was eager for a fight.

Alvin's military background tried to speak up more sternly this time. "Sir, behave."

“Behave?” Ralph burst out laughing. "Look, you lot love our tourist dollars. Deal with it, kid."

Winifred could not believe what she was hearing. Ralph might be patronising but never racially so. Despite his rough exterior, he was a scholar and drawn to the cultures of the region. The mood swing devils were rebelling in his head.

Alvin stood up and stepped forward.

Ralph pushed him back with an open palm like a tai chi expert.

Alvin stumbled off balance, knocking his hand against the seat. The velvet box fell at Winifred's feet.

She retrieved the precious item, but Ralph pounced and snapped it open. Meaty fingers fumbled the precious object from its satin mounting. "Well, well, well. Go figure. A diamond ring."

"Give it back!" Alvin demanded.

Too late. Ralph had claimed the prize as pirate booty. Next, he shifted his attention to Fay. “Hey, little sister, so this one's meant for you, huh? Well, I wouldn't trust a guy who let a sparkler like this out of his grasp."

Fay's angry face agreed. How could Alvin have put her in this fix? Had he planned to propose? The entire business was so embarrassing.

Alvin was getting riled. "I said give it back!"

Ralph moved the ring away from the young man's grasping hand. "How's about a pretty please?"

"Stop it!" Winifred said.

"Serves him right, Winnie."

Alvin made one more grab for the ring, but the older man turned, adroit as a dancer using his back as a shield. They tussled. The ring bounced under the seating. Alvin's wire-frame glasses went flying, too. 


\section{SARE, Vol. 57, Issue 1/2020}

— Ah Kok, shine your torch!

Fay shielded herself from the glare and the embarrassment while Alvin found his glasses and continued scrabbling on all fours. He felt humiliated in front of Fay. Why did all this have to happen tonight? An overpowering urge to get up and punch the tourist in the face consumed him. He entertained the thought of hammering a fist into the man's flesh until a deeper voice spoke. You cannot hit him. He is twice your age and a drunk. How would his wife feel? Alvin's sense of humiliation and loss of face in front of Fay were nothing compared with the need to practice restraint inculcated in him by his Buddhist upbringing. What would his mother say? He breathed harder, chanting his Amitabha mantra. Doing so, oxygenated and soothed his brain. The diamond ring still needed finding, even though he knew she would probably never want to wear it. He swallowed his pride and the remorse for having entertained such violent thoughts. It made him scuttle harder, sideways like a crab, searching for that useless bauble that had cost three pay cheques. Alvin suffered a fresh sensation. Was it the pain of shame or the taste of humility? It was hard to tell the difference between them.

Winifred winced at what had happened. She looked hard at her husband.

"What?" He feigned innocence. The evidence of the ring box was still in his hand.

Winifred grabbed it from him as if removing contraband toffees from a child. She was fed up. "You always make a mess of things, don't you?"

Ralph looked worn out. His spike of adrenaline had waned.

The boatman's flashlight snaked here and there beneath the seating. Sure enough, the ring was within reach. Winifred scooped and stepping between Ralph and the young man handed both the box and its precious object back to Alvin. Instinctively he pocketed the ring but kept the box in his hand as she whispered. "My husband has a medical condition and should not be drinking. All this is so unfortunate. I am so sorry."

Alvin struggled to control his feelings but was not one to hold grudges, especially as the Australian woman's sincerity made up for her husband's misbehaviour. He nodded with a tired smile.

"Thank you." Winifred now turned back to her side of the boat and pushed Ralph along the seat, becoming a buffer between the two. She could see that the young man's plan had taken a disastrous turn, and it was more tactful not to say anything about it.

Alvin looked ahead, passing the ring box between his hands until he knew Fay was staring 


\section{SARE, Vol. 57, Issue 1/2020}

sideways at the item. He cupped it in his palms and then put it away.

She moved her eyes away to the water. What could she do or say after this unfortunate turn of events? Despite the foreigner's apparent condition, his abusive behaviour still appalled her, and she felt doubly sorry for the Australian wife. It would be an incident to relate at her next Aware study group meeting. Then, there had been Alvin trying to impress her with his promotion. She felt sorry for him, guilty, even, but what was he thinking- proposing when they hardly knew each other? Now tonight, despite her goading, Alvin showed himself to be too weak to stand up to the Australian tourist. It was crystal clear that he was not her type. Deep down though, she knew that she was partly responsible for what had happened these past months because she had not clarified her feelings toward him. All she could think of was Phillip, which was equally degrading. Out of her life for a year would he contact her? Desire was eating her up. How desperately she wanted to go home, climb into bed, pull the comforter printed with unicorns up over her head and forget this bad-news evening.

By now the bumboat engine had completed the last leg of its full figure-eight to arrive back at the same jetty. The four passengers braced themselves as the bump-tyre nudged against the pylon once more. Ah Kok came forward to lasso the mooring post.

Fay stood to flee, letting Alvin's grey jacket slip like a discarded skin to the floor. She could not bear to speak to him.

Everything had turned sour despite his planning. He also got up with the hope of making things right.

Fay was having none of it. Her hit-and-run tongue lashed out. "Just leave me alone!" He froze as she climbed out of the boat, crossed the jetty and moved with quickening pace toward the taxi stand.

The American urged him on, "Go after her."

The mood pendulum had swung back to a calm place.

Alvin shot the troublemaker a hard look. How could he even utter a word now? New anger wanted to rise but he clenched it in both his fists.

“Sorry buddy, I messed up bad before, but you gotta trust me. It ain’t too late."

"Please listen," Winifred insisted, glad that Ralph had come to his senses.

"Look son, sometimes 'Leave me alone' means 'try harder."”

The man, despite his unacceptable behaviour, made sense. There was no time to waste. Alvin climbed out of the boat to catch up to her. 


\section{SARE, Vol. 57, Issue 1/2020}

By the time Alvin had cleared the prow and jetty, Ralph also stood up. He felt wobbly from the alcohol.

The sad turn of circumstances had softened Winifred. Her husband needed the forgiving local patois of her touch and a supporting arm. Still holding the notebook, her hand came around from behind to joist her silly mood-flip man up and forward.

Ralph glimpsed Winnie's sketch at the side of her sentence scribbles. "Sorry, Amanda darlin'," he said to the picture.

“Come on, you big galoot. You've done enough damage for one night.” She helped him out of the boat to find the same path back to the hotel.

He swayed this way and that, staggering too close on one side to the long, rectangular topiary of the ixora hedge, its red flowers decapitated by municipal secateurs, until something landed on his shoulder: a long green stick-thing with a triangular head like an alien. He flicked it off with creepy-crawly repulsion and the bug with jagged forearms opened wings to take sudden flight.

"It's just a praying mantis. It won't hurt you," Winifred said. She was used to sketching insects up close.

Now that the sudden rain pelted down. They had to make a run for it.

- Ah Kok, what have you got to say for yourself?

He stands, mid-aisle, with hands on hips, sheltered from the sudden monsoon downpour and shaking his head.

- You could have smoothed things over. You could have jerked the wheel left or right many times. A solid shake would make him sit down; or you might have even sung something to change the mood.

"Boss, you say the Water Clan cannot interfere, what!"

- So conveniently, you forget your training, Ah Kok. This is your boat. You have full jurisdiction. When people get hurt, it is our fault.

"Boss, all this is ve-ry confusing leh."

- It will have to go in the Log. We write our story whether good or bad.

"Those people are trouble. Like hungry ghosts but still alive."

Ah Kok lunges with open palms at the passengers disappearing. 


\section{SARE, Vol. 57, Issue 1/2020}

— Sending all the cleansing chi will not help! Trouble just doesn't wash away. I will have to find out why.

He is not listening. Instead, Ah Kok picks up Ralph's Singapore dollar that had rolled all the way to the back before the ride.

- Why you did not give it back? The coin was there all along.

The bumboat driver shrugs his shoulders.

- Still have a lot to learn, Ah Kok.

No answer.

I will have to deal with him later because I see fresh trouble about to fall flat on its face. 